Federal Reserve Bank of Minneapolis

Research Department Staff Report 460

July 2011

\title{
A Model of Commodity Money with Minting and Melting*
}

\author{
Angela Redish \\ University of British Columbia \\ email: angela.redish@ubc.ca \\ Warren E. Weber \\ Federal Reserve Bank of Minneapolis \\ e-mail: wew@minneapolisfed.org
}

\begin{abstract}
We construct a random matching model of a monetary economy with commodity money in the form of potentially different types of silver coins that are distinguishable by the quantity of metal they contain. The quantity of silver in the economy is assumed to be fixed, but agents can mint and melt coins. Coins yield no utility, but can be traded. Uncoined silver yields direct utility to the holder. We find that optimal coin size increases with the probability of trade and with the stock of silver. We use these predictions of our model to analyze the coinage decisions of the monetary authorities in medieval Venice and England. Our model provides theoretical support for the view that decisions about coin sizes and types during the medieval period reflected a desire to improve the economic welfare of the general population, not just the desire for seigniorage revenue.
\end{abstract}

*The figures are best viewed in color. We thank Miguel Molico, François Velde, Randy Wright, and participants at seminars at the Federal Reserve Bank of Boston, the University of British Columbia, Yale University and the University of Oxford for helpful comments. Redish gratefully acknowledges the support of the Social Sciences and Humanities Research Council of Canada. The views expressed in this paper are those of the authors and not necessarily those of the Federal Reserve Bank of Minneapolis or the Federal Reserve System. 
Any study of the money supply [of medieval Europe] needs to take account not only of the total face value of the currency, but also of the metals and denominations of which it is composed. (Mayhew (2004), p. 82)

For nearly a millennium, European monetary systems were based on commodities, specifically silver or gold and silver coinage. Theoretical understanding of commodity money systems most often derives from the 19th-century gold standard and is founded on a quantity theory approach to money, which focuses on the role of the quantity of the commodity in setting the price level and the neutrality of changes in that quantity for changes in output.

Such theorizing misses much of the richness of monetary history. Economists, historians, and numismatists have identified numerous challenges that faced the monetary authorities of medieval Europe, including dealing with bullion famines (and feasts) and the scarcity or surfeit of small change. The quantity theory of money is inherently unable to address these issues for a commodity money system. It assumes that the supply of money is controlled by a monetary authority, at least indirectly, and that money is perfectly divisible. Further, it does not explicitly model the medium of exchange function of money.

In this paper, we take a different approach to analyzing commodity money systems. We build a random matching model of monetary exchange in which agents need to use coins as a medium of exchange to buy (perishable) goods. We assume an exogenously fixed quantity of a non-perishable good (silver) that can be held in a utility-yielding form (which we call "jewelry") or can be held as coins that do not yield utility directly but can be traded with other agents. Agents can acquire coins (at a cost) by taking jewelry to the mint or can acquire jewelry by melting coins. The monetary authority determines the size of (amount of silver in) a coin and the number of types of coins in existence. Using numerical examples, we show that the weight of silver per coin matters for economic welfare and that changes in the frequency of trading opportunities and in the quantity of monetary metal affect the optimal coin size.

We then use the model to analyze the choices of coin size in Venice and England through the Middle Ages. These two locations are used in part because they are relatively well documented and in part because they represent two different economic environments. Both regions became urbanized in the Middle Ages, but Venice more so and earlier. Both regions also experienced an influx of silver - again earlier in the case of Venice. In the context of our model, such differences and changes in the economic environment would imply that different coin sizes would maximize social welfare. We show that the monetary authorities in the two regions changed the types of coins issued in the way that the model predicts would have increased social welfare. In other words, our model provides theoretical support for the view that decisions about coin sizes during the medieval period reflected, at least in part, a desire to improve the economic welfare of the general population, not just the desire for seigniorage revenue on the part of the sovereign.

Our model is closely related to that of Velde and Weber (2000) and Lee, Wallace, and Zhu (2005). Velde and Weber (2000) model a commodity money system allowing agents to hold monetary metal as coins or in a form that yields direct utility. The demand for money in their model is driven by a cash-in-advance constraint. Lee, Wallace, and Zhu (2005) build a random matching model in which agents can hold multiple units of various types of fiat money. Agents engage in pair-wise trade alternately with periods where they can 
rebalance their portfolio subject only to a wealth constraint. They prove the existence of a monetary steady state in which agents trade off the benefits of small denomination notes for transacting against their higher handling costs. As in Lee, Wallace, and Zhu (2005), we motivate the demand for money with a random matching model. However, our agents use a commodity money and thus there is an additional margin - the marginal utility of jewelry - that bears on how many coins an agent wants to hold.

In a previous paper (Redish and Weber (2011)), we built a random matching monetary model with two indivisible coins and illustrated that a small change shortage could exist in the sense that adding small coins to the economy with large coins was welfare improving. However, in that paper we assumed a fixed quantity of coins of each type and compared the characteristics of equilibria with different stocks and sizes of coins. The commodity value of the coins was imposed by assuming that each coin paid a dividend (essentially was a Lucas tree). In this paper we endogenize the quantity of money by permitting minting and melting. Thus the model combines a more fundamental way of generating valued commodity money with an endogenous quantity of money (though not an endogenous quantity of monetary metal), thereby providing a much richer framework in which to discuss medieval monetary systems.

The paper proceeds as follows. In the next section we describe the types of silver coinage produced in the mints of Venice and England between 800 and 1400. Section 2 then presents a model of a monetary system that enables us to evaluate the consequences of different denomination structures. Section 3 presents some characteristics of the steady state of the model. Section 4 then uses the results to argue that the changes in denomination structure in medieval Venice and England are consistent with those that would have been welfare-improving responses to the changing economic environment: the expansion in markets and the rising stock of silver. Section 5 contrasts our results with those in the literature. The final section concludes.

\section{The monetary system}

From the time of Charlemagne until the end of the 12th century, European governments essentially minted only a single type of coin variously called the denarius, denier, or penny depending on the location. ${ }^{1}$ Charlemagne standardized the coinage of the many mints in the Holy Roman Empire with a denarius of high fineness, a diameter of about $18 \mathrm{~mm}$., and a weight of about 1.7 grams. The English, not part of the empire, also minted a silver coin that was similar in fineness and weight to the denarius. Although pennies were the sole coin minted, accounts often used the collective noun shilling (or sol) to refer to a dozen pennies, and pound (or lire) to refer to a score of dozens (240 pence).

The uniformity that Charlemagne imposed did not outlive him. Within the empire, counts began operating their mints on their own account, and throughout Europe minting rights were assumed by bishops and seigneurs (the origin of the term "seignorage") who became the local monetary authority. Each monetary authority chose the weight and fineness

\footnotetext{
${ }^{1}$ Some German states issued very different coins called "bracteates" that were thin, had a large diameter, and were stamped only on one face. A few states that issued deniers also minted obols - half deniers however, the extent of this coinage is hard to know. We follow Favier (1998), p. 127, who speaks of "the single denomination the denier and nothing but the denier."
} 
Table 1: The penny coinages of the late 12th century

\begin{tabular}{l|rrcr} 
& Year & Weight & Fineness & Fine weight \\
\hline \hline England & 1160 & $1.46 \mathrm{gms}$ & .925 & $1.35 \mathrm{gms}$ \\
Cologne & 1160 & $1.4 \mathrm{gms}$ & .925 & $1.30 \mathrm{gms}$ \\
Paris & 1160 & $1.28-0.85 \mathrm{gms}$ & $<.5$ & $<.60 \mathrm{gms}$ \\
Melgueil & 1125 & $1.1 \mathrm{gms}$ & .42 & $0.46 \mathrm{gms}$ \\
Lucca & 1160 & $0.6 \mathrm{gms}$ & 0.6 & $0.36 \mathrm{gms}$ \\
Barcelona & 1160 & $0.66 \mathrm{gms}$ & 0.2 & $0.13 \mathrm{gms}$ \\
Venice & 1160 & & & $0.1 \mathrm{gms}$ fine
\end{tabular}

Note: a U.S. dime weighs 2.268 grams.

Source: Spufford (1988), pp. 102-3. Lane and Mueller (1985), p. 527.

of the penny that it minted, and all diminished both but to very different extents. By the mid-12th century, the characteristics of the penny ranged widely (see Table 1) from the English penny, weighing 1.46 grams and $92.5 \%$ fine, to the many French coins weighing about 1 gram and about $35 \%$ fine, to the Italian coins that were about one-quarter of a gram and less than 30\% fine (Spufford (1988), pp. 102-3).

The use of a single type of coin in an economy made payments of both small and large amounts difficult. In England, for example, the daily wage for a laborer in 1250 was roughly one penny (Britnell (2004), p. 24), and a penny would buy 9 or 10 gallons of ale or four 1 pound loaves of bread. Throughout Europe the options for paying large values were also limited. There were some Byzantine gold coins, particularly in the South of Europe. Silver ingots, stamped with their fineness and often weighing an integer number of marks (a mark weighed about 220 grams), were used on occasion. But even for large payments, pennies were used, frequently in sealed bags certified for their contents. Spufford (1988) p. 210 cites the example of the papal collector for northern Europe who collected over 70,000 marks in pence (close to 1 million pence!), as well as over 1,000 marks in ingots for remittance to the pope.

The practice of minting only a single type of coin ended in Italy in the last decade of the 12th century. In 1190 the Milanese began minting a grosso that was of high fineness and weighed over 2 grams. This coin only circulated locally, but a few years later the Venetians began minting a similar coin which circulated widely. The Venetian grosso contained roughly 24 times as much silver as the denari that were in circulation. The French followed suit (see Table 2), introducing the gros tournois in 1266.

The English, in contrast, did not issue a larger coin until much later. Instead, beginning in 1279, the Royal Mint issued two smaller coins that were fractions of a penny: the halfpenny and farthing (quarter penny). England did not issue a coin larger than the penny until the groat in $1351 .^{2}$

\footnotetext{
${ }^{2}$ The mint ordinance of 1279 allowed the minting of groats. However, numismatists argue that essentially none were minted between 1279 and 1344; see Section 4.2 below.
} 


\begin{tabular}{l|llcc} 
Table 2: The introduction of new silver coins, 13th and 14th centuries \\
& Metal & Fine weight & $\begin{array}{c}\text { Value in } \\
\text { unit of account }\end{array}$ \\
\hline Venice & & & & \\
1172 & Denarius & Silver & $.10 \mathrm{gms}$ & $1 \mathrm{~d}$ \\
1194 & Grossus & Silver & $2.1 \mathrm{gms}$ & $24 \mathrm{~d}$ \\
1284 & Grossus & Silver & $2.1 \mathrm{gms}$ & $32 \mathrm{~d}$ \\
France & & & & \\
1200 & Denier & Silver & $0.36 \mathrm{gms}$ & $1 \mathrm{~d}$ \\
1266 & Gros tournois & Silver & $4.2 \mathrm{gms}$ & $12 \mathrm{~d}$ \\
England & & & & \\
1200 & Penny & Silver & $1.4 \mathrm{gms}$ & $1 \mathrm{~d}$ \\
1279 & Farthing & Silver & $.34 \mathrm{gms}$ & $.25 \mathrm{~d}$ \\
1351 & Groat & Silver & $4.33 \mathrm{gms}$ & $4 \mathrm{~d}$
\end{tabular}

Sources: Lane and Mueller (1985), de Wailly (1857), Challis (1992).

\section{The Model}

\section{A. Environment}

We build a random matching model in which agents are permitted to hold multiple numbers of each of two types of coins. The model has discrete time and an infinite number of periods. There is a nonstorable, perfectly divisible good and a durable commodity, silver. There are $m$ ounces of silver per capita in existence.

The way in which we model commodity money follows that used by Velde and Weber (2000). We assume that silver can be held in either of two forms, which we refer to as coins and jewelry. Silver held in the form of jewelry yields utility directly to the holder, whereas silver held in the form of coins yields no utility to the holder. Only coins can be traded, because of difficulties in determining the weight and fineness of jewelry. There is a per-period utility cost $\gamma$ of holding a coin that is independent of the size of the coin.

The technological limitations on minting in the medieval period placed restrictions on what the monetary authority could do with coinage. Coins could not be too small, because of the possibility of loss. Also, they could not be too heavy or they would be difficult to carry. Further, difficulties in determining weight and fineness imposed restrictions on how similar different types of coins could be. The role of the monetary authority in this environment was to choose how many ounces of metal to put into a coin and how many types of coins to mint subject to these limitations.

In our model, we allow for the minting of two types of silver coin distinguished by the weight of silver in each coin. We let $b_{1}$ be the ounces of silver that it puts in the first silver coin, and $b_{2}=\eta b_{1}$ be the amount of silver in the second coin, where $\eta$ is an integer greater than one. As was the case with coins throughout most of the time during which commodity monies were used, these coins do not have denominations. They are simply an amount of silver that has been turned into coins with some type of standardized markings that allow one type of coin to be easily differentiated from a different type of coin. 
Each period in the model is divided into two subperiods. In the first subperiod agents can trade in bilateral matches. At the beginning of this subperiod, an agent has a probability

$\frac{1}{2}$ of being a consumer but not a producer and the same probability of being a producer but not a consumer. This assumption rules out double coincidence matches, and therefore gives rise to the essentiality of a medium of exchange.

After agents' types (consumer or producer) are revealed, a fraction $\theta^{\prime} \in(0,1]$ of agents are randomly matched bilaterally. In a match, the portfolios of both agents are known. However, past trading histories are private information, and agents are anonymous. These assumptions rule out gift-giving equilibria and the use of credit. Thus, trading can occur only through the use of media of exchange, which is the role that the silver coins can play.

In the second subperiod, agents can alter their mix of the two types of silver coins and jewelry by minting or melting. That is, in the second subperiod agents can change the form in which they hold the stock of silver, but they cannot change the total quantity in the economy.

\section{B. Consumer choices}

There is a $[0,1]$ continuum of infinitely lived agents in the model that maximize expected discounted lifetime utility. The discount factor is $\beta$. Let $c$ be the quantity of the good consumed; $q$, the quantity of the good produced; and $j$, the holdings of silver jewelry in terms of units of the small coin. The agent's period preferences are

$$
u(c)-q+\mu\left(b_{1} j\right)
$$

with $u(0)=0, u^{\prime}>0, u^{\prime \prime}<0$, and $u^{\prime}(0)=\infty$. The disutility of good production is assumed to be linear without loss of generality. We assume that an agent's utility from holding silver jewelry is $\mu\left(b_{1} j\right)$ with $\mu^{\prime}>0, \mu^{\prime \prime}<0$. Let $s_{1}$ and $s_{2}$ be an agent's holdings of small and large silver coins, respectively. The agent's portfolio of metal holdings is $y=\left\{\left(s_{1}, s_{2}, j\right)\right.$ : $\left.s_{1}, s_{2}, j, \in \mathbb{N}\right\}$.

We assume that in a single coincidence pairwise meeting, the potential consumer gets to make a take-it-or-leave-it (TIOLI) offer to the potential seller. This offer is the triple $\left(q, p_{1}, p_{2}\right)$, where $q \in \Re_{+}$is the quantity of production demanded and $p_{i} \in \mathbb{Z}$ is the quantity of silver coins of type $i$ offered. Offers with $p_{1}<0$ can be thought of as the seller being asked to make change.

Let $v(y): \mathbb{N} \otimes \mathbb{N} \rightarrow \Re_{+}$be the expected value of an agent's portfolio at the beginning of the second subperiod. The set of feasible TIOLI offers is a combination of output and coins that is a feasible coin offer and satisfies the condition that the seller be no worse off than not trading. We denote this set by $\Gamma(y, \tilde{y})$,

$$
\begin{aligned}
\Gamma(y, \tilde{y})= & \left\{\left(q, p_{1}, p_{2}\right): q \in \Re_{+},-\tilde{s_{1}} \leq p_{1} \leq s_{1},-\tilde{s_{2}} \leq p_{2} \leq s_{2},\right. \\
& \left.-q+v\left(\tilde{s_{1}}+p_{1}, \tilde{s_{2}}+p_{2}, \tilde{j}\right) \geq v(\tilde{y})\right\}
\end{aligned}
$$

where $\mathrm{a}^{\sim}$ denotes the seller. In the second subperiod, the agent can mint or melt. Define $z_{i} \in \mathbb{Z}$ to be the quantity of silver coins of type $i$ minted $(>0)$ or melted $(<0)$. Agents cannot melt more coins than they have, and agents cannot mint more coins than they have 
metal in the form of jewelry. Note that this does not prevent them from melting coins of one type and minting coins of the other from the metal gained by melting. Denote the set of minting and melting choices available to an agent by $\Omega(y)$ :

$$
\Omega(y)=\left\{\left(z_{1}, z_{2}\right): z_{i} \geq-s_{i}, z_{1}+\eta z_{2} \leq j\right\} .
$$

Agents can melt coins without incurring a cost. However, if agents mint, they incur a seigniorage cost $S\left(z_{1}, z_{2} ; j\right)$. To keep the analysis tractable, we assume that no metal is lost by an agent when minting. Instead, we assume that the seigniorage an agent has to pay is in terms of utility, but does depend on how many coins are minted.

\section{Equilibrium}

The three components needed are the value functions (Bellman equations), the asset transition equations, and the market clearing conditions. We proceed to describe each in turn.

\section{Value functions}

Let $w_{t}\left(y_{t}\right)$ and $v_{t}\left(y_{t}\right)$ be the expected values of holding $y_{t}$ at the beginning of the first and second subperiods of period $t$, respectively. The Bellman equation at the beginning of the second subperiod is

$$
v_{t}\left(y_{t}\right)=\max _{\left(z_{1 t}, z_{2 t}\right) \in \Omega\left(y_{t}\right)}\left\{\beta w_{t+1}\left(s_{1 t}+z_{1 t}, s_{2 t}+z_{2 t}, j_{t}-z_{1 t}-\eta z_{2 t}\right)-S\left(z_{1 t}, z_{2 t} ; j_{t}\right)\right\}
$$

The Bellman equation at the beginning of the first subperiod is

$$
\begin{aligned}
w_{t}\left(y_{t}\right)= & \theta \sum_{\tilde{y}_{t}} \pi_{t}\left(\tilde{y}_{t}\right) \max _{\left(q_{t}, p_{1 t}, p_{2 t}\right) \in \Gamma\left(y_{t}, \tilde{y}_{t}\right)}\left[u\left(q_{t}\right)+v_{t}\left(s_{1 t}-p_{1 t}, s_{2 t}-p_{2 t}, j_{t}\right)\right] \\
& +(1-\theta) v_{t}\left(y_{t}\right)+\mu\left(b_{1} j_{t}\right)-\gamma\left(s_{1 t}+s_{2 t}\right)
\end{aligned}
$$

where $\pi_{t}\left(y_{t}\right)$ is the fraction of agents with $y_{t}$ at the beginning of the first subperiod and $\theta=\frac{\theta^{\prime}}{2}$. The first term on the right-hand side is the expected payoff from being a buyer in a single coincidence meeting, which occurs with probability $\theta$. The second term is the expected payoff either from being the seller in a single coincidence meeting or from not have a meeting. The third term is the utility from holding silver jewelry, and the final term is the utility cost of carrying silver coins.

\section{Asset holdings}

Define $\lambda^{b}\left(k_{1}, k_{2} ; y_{t}, \tilde{y}_{t}\right)$ to be the probability that a buyer with $y_{t}$ meeting a seller with $\tilde{y}_{t}$ leaves with $s_{1}-p_{1}=k_{1}$ and $s_{2}-p_{2}=k_{2}$. That is,

$$
\lambda^{b}\left(k_{1}, k_{2} ; y, \tilde{y}\right)= \begin{cases}1 & \text { if } k_{1}=s_{1}-p_{1}(y, \tilde{y}) \text { and } k_{2}=s_{2}-p_{2}(y, \tilde{y}) \\ 0 & \text { otherwise. }\end{cases}
$$

Define $\lambda^{s}\left(k_{1}, k_{2} ; y_{t}, \tilde{y}_{t}\right)$ similarly for the seller. 
The post-trade (pre-mint/melt) asset distribution is

$$
\begin{aligned}
\pi_{t}^{\prime}\left(k_{1}, k_{2}, j\right)= & \theta \sum_{y_{t}, \tilde{y}_{t}} \pi_{t}\left(y_{t}\right) \pi_{t}\left(\tilde{y}_{t}\right)\left[\lambda^{b}\left(k_{1}, k_{2} ; y_{t}, \tilde{y}_{t}\right)+\lambda^{s}\left(k_{1}, k_{2} ; y_{t}, \tilde{y}_{t}\right)\right] \\
& +(1-2 \theta) \pi_{t}\left(k_{1}, k_{2}, j\right)
\end{aligned}
$$

where' denotes the beginning of the second subperiod. The first term on the right-hand side is the fraction of single coincidence meetings in which the buyer leaves with $k_{1}$ small silver coins and $k_{2}$ large silver coins. The second term is the fraction of such meetings in which the seller leaves with $k_{1}$ small silver coins and $k_{2}$ large silver coins. The final term is the probability that no meeting occurs, in which case no coins change hands.

Next define $\delta\left(k_{1}, k_{2}, h, y_{t}\right)$ to be the probability an agent with $y_{t}$ after trade has $s_{1}+z_{1}=k_{1}, s_{2}+z_{2}=k_{2}$, and $j-z_{1}-\eta z_{2}=h$ after minting or melting. Then the post-mint/melt (pre-trade next period) asset distribution is

$$
\pi_{t+1}\left(k_{1}, k_{2}, h\right)=\sum_{y_{t}^{\prime}} \pi_{t}^{\prime}\left(y_{t}^{\prime}\right) \delta\left(k_{1}, k_{2}, h, y_{t}^{\prime}\right)
$$

Of course, asset holdings must also satisfy $\sum_{y} \pi(y)=\sum_{y} \pi^{\prime}(y)=1$.

\section{Market clearing}

The market clearing condition is that the stock of silver metal must be held. That is,

$$
\sum_{y} b_{1}\left(s_{1}+\eta s_{2}+j\right) \pi(y)=m .
$$

Definition 1. Steady state equilibrium: A steady state equilibrium is value functions $w, v$; asset holdings $\pi$ and $\pi^{\prime}$; and quantities $p_{1}, p_{2}, z_{1}, z_{2}, q$ that satisfy the value functions, the asset transition equations, and market clearing.

\section{Results}

We are unable to prove the existence of steady state equilibria or to obtain analytic results for our model. Therefore, we rely on computed equilibria for numerical examples to obtain our results. Specifically, we assume $u(q)=q^{1 / 4}, \mu\left(b_{1} j\right)=0.05\left(b_{1} j\right)^{1 / 2}, \beta=0.9$, and $\gamma=0.001$. Because we are interested in the effects of changes in the size of coins, urbanization, and the stock of silver, we consider various values for $b_{1}, \eta, \theta$, and $m$.

To avoid problems in keeping track of the quantity of silver in the economy, we define seigniorage in terms of foregone utility from holding jewelry. Specifically, we assume

$$
S\left(z_{1 t}, z_{2 t} ; j_{t}\right)=\max \left\{\mu\left(b_{1} j_{t}\right)-\mu\left[b_{1} j_{t}-b_{1} \sigma\left(z_{1 t}+\eta z_{2 t}\right)\right], 0\right\}
$$

where $\sigma$ is the seigniorage rate. The term $\mu\left(b_{1} j_{t}\right)$ is the utility from holding jewelry before doing any minting. The term $\mu\left[b_{1} j_{t}-b_{1} \sigma\left(z_{1 t}+\eta z_{2 t}\right)\right]$ is the utility from holding that amount of jewelry less the amount of jewelry given up to pay the seigniorage tax on minting coins from jewelry. The max with 0 is because seigniorage is only paid on minting. We use a 
seigniorage rate of $\sigma=0.04$, which was approximately the average seigniorage rate on silver during this period.

\section{A. Single silver coin}

Because of the long period in which there was only a single silver coin in medieval Europe and to get some intuition about how the model works, we begin by studying our economy when there is only a single silver coin. Ex ante welfare in this economy depends upon the size of the coin. ${ }^{3}$ This is shown in Figure $1 .{ }^{4}$ We assume $\theta=1 / 3$ and $m=0.1$ for this example.

The optimal size coin is $b_{1}=0.009$. It reflects the trade-off between the amount an agent can get in a trade and the cost of carrying a coin. Having a single large-size coin in the economy saves on handling costs, but it means that potential buyers with coins are willing to trade only if they encounter a potential seller who is willing to produce a large quantity of output. Such meetings occur infrequently, because the only potential sellers who are willing to produce a large quantity of output are those with small holdings of silver wealth. In contrast, a small-size coin increases handling costs, but means that potential buyers are willing to trade when they encounter potential sellers who are willing to produce a smaller quantity of output. Such meetings occur more frequently, because there is a larger fraction of such potential sellers. Note that handling costs are critical in the determination of optimal coin size. For example, if $\gamma$ were equal to zero, then it would be optimal to make the coin infinitely small.

Because the types of trades that occur differ depending on the size of the coin for the reasons just stated, the distribution of coin and jewelry holdings depends on the size of the coin. This is illustrated in Figure 2, which shows coin and jewelry holdings for coin sizes of $b_{1}=0.009$ and $b_{1}=0.015$. The figure shows that with a larger coin there are more agents who do not have coins, implying that fewer trading opportunities are available. It also shows that, for any level of silver holdings (in terms of units of coins, not ounces of metal), agents hold more silver wealth in the form of jewelry and less in the form of coins when the larger coin is the only one in existence.

It is also useful to examine how the distribution of welfare changes with coin size. This is done in Figure 3, where we plot the cumulative distribution of agents by their welfare for coin sizes of $b_{1}=0.009$ and $b_{1}=0.015$. The measure of agents in the economy with low levels of welfare increases with coin size, and the measure of agents with high levels of welfare decreases. Further, the measures of gainers and losers are not necessarily equal. Even though ex ante welfare is higher when $b_{1}=0.009$, only $40 \%$ of agents experience a higher level of welfare. One way to interpret this result is the following. Suppose a vote were taken but agents did not know where they would end up in the welfare distribution (ex ante welfare). Then they would prefer $b_{1}=0.009$. However, if agents knew that they would end up at the same point in the cumulative welfare distribution, then the majority would

\footnotetext{
${ }^{3}$ Throughout the analysis, our welfare criterion is ex ante welfare, computed as $\bar{w}=\sum_{y} \pi(y) w(y)$. For comparison, we note that ex ante welfare in an economy in which a planner could instruct agents to give gifts of the optimal quantity of output $q^{*}=0.1575$ is $\bar{w}=1.733$. Welfare in the planner economy is higher because agents could use all the silver for utility-yielding jewelry and because the level of output produced/exchanged would not depend on the coin-holdings of each party.

${ }^{4}$ All computations for ex ante welfare and the figures are done using a grid size of 0.001 for $b_{1}$.
} 


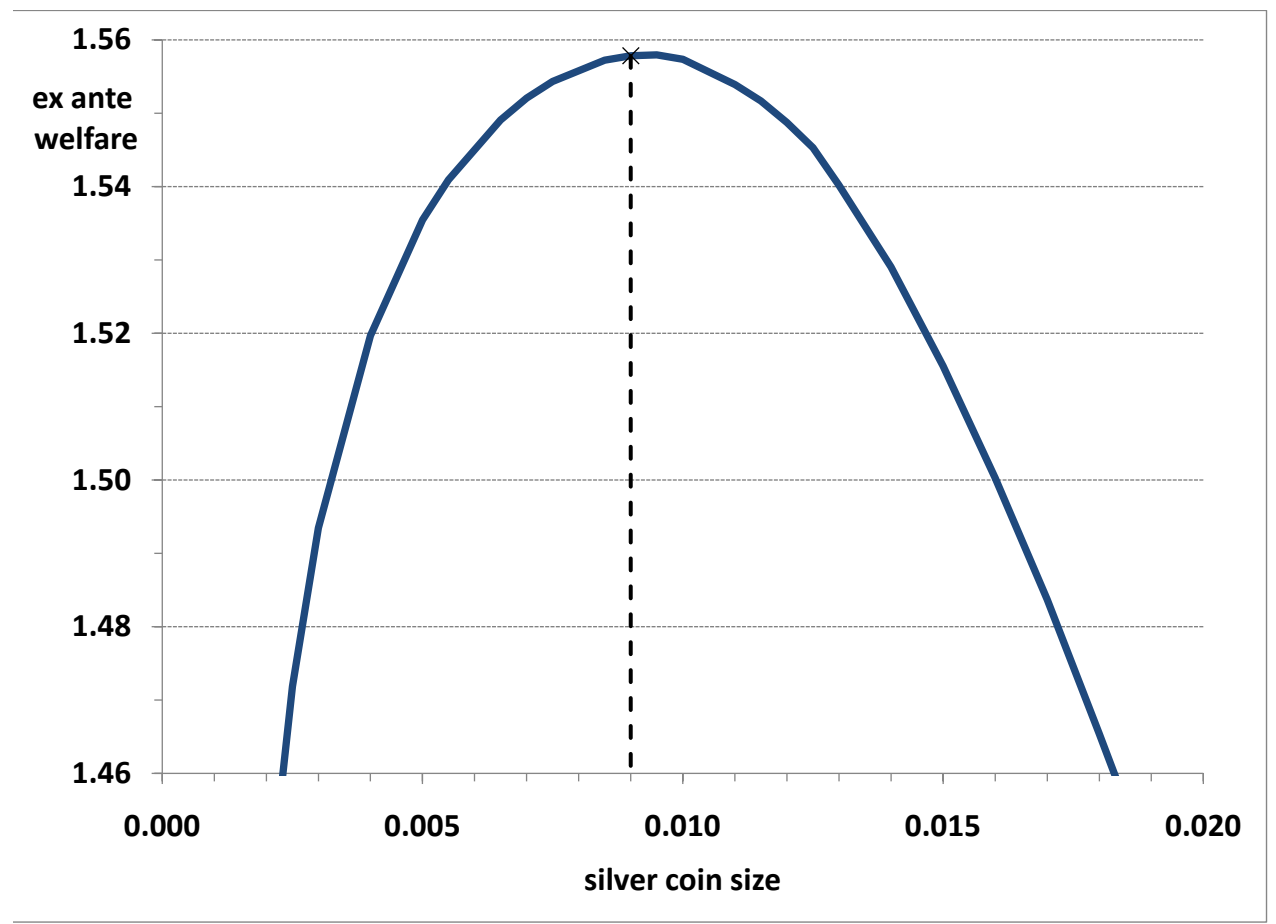

Figure 1: Ex ante welfare for various sizes of coins

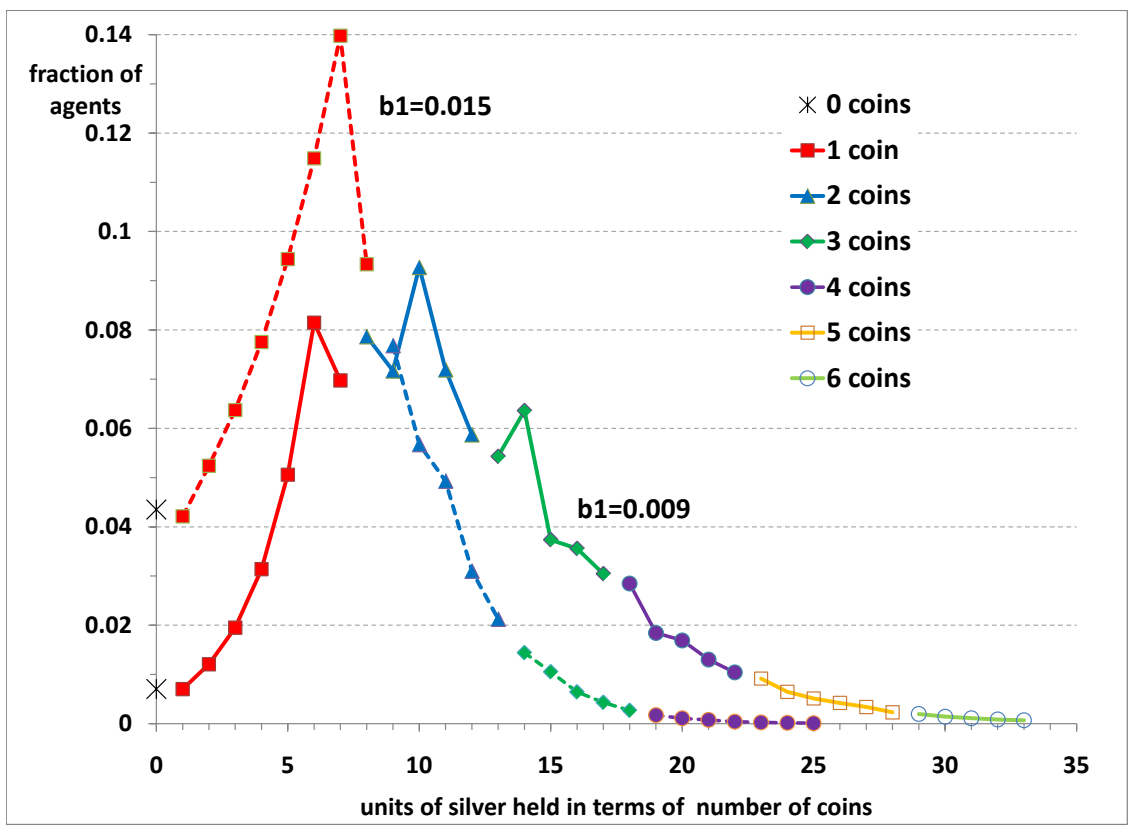

Figure 2: Distribution of coin and jewelry holdings, $b_{1}=0.009$ and $b_{1}=0.015$ 
prefer $b_{1}=0.015$. An implication is that if the monetary authority puts more weight on the wealthy, as might be the case for a sovereign who favors nobles over peasants, it might choose a larger coin size than would a more equalitarian monetary authority.

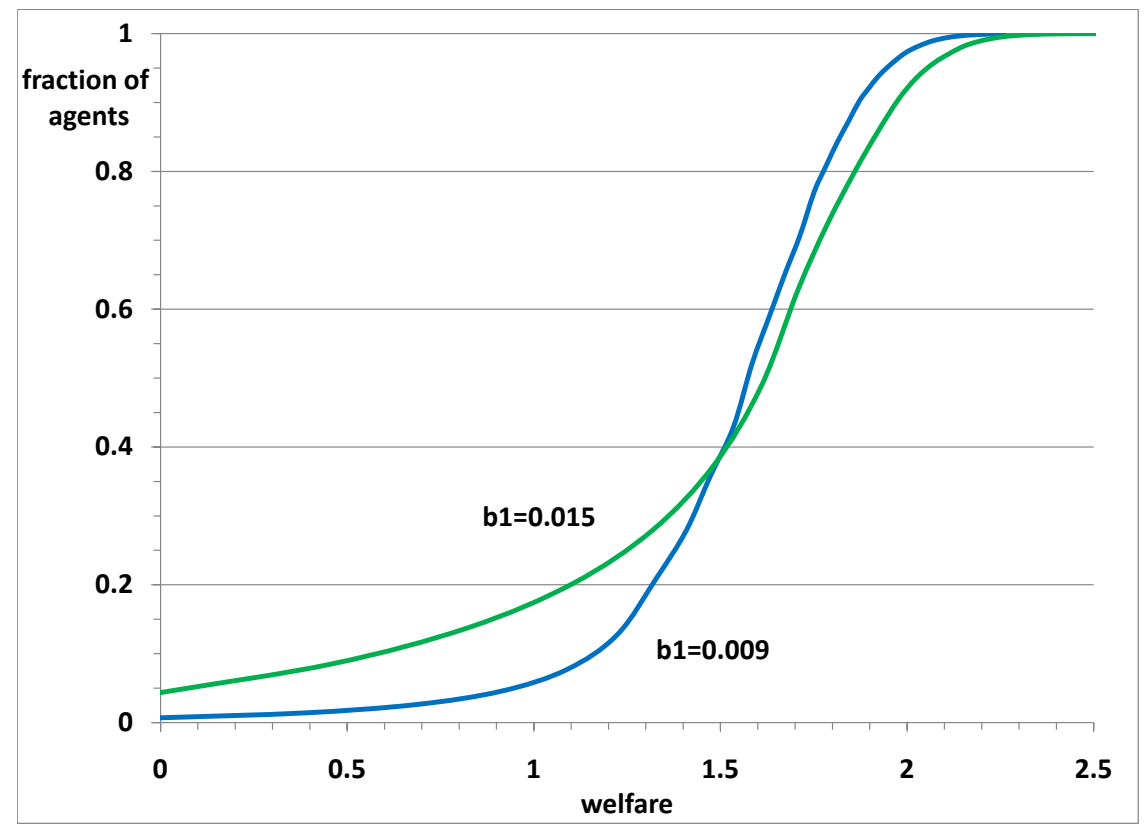

Figure 3: Cumulative distribution of silver holdings, $b_{1}=0.009$ and $b_{1}=0.015$

\section{B. Two coins}

We turn now to the case in which the monetary authorities permit the minting of coins of two different sizes. The agents who carry silver jewelry to the mint can opt for large or small silver coins, and equally can melt large or small coins into jewelry. In Figure 4 the curves depict ex ante welfare in an economy with two coin types where the second coin's weight is $\eta=3$ times that of the original coin. Again, we assume $\theta=1 / 3$ and $m=0.1$.

The figure illustrates a number of features of the model.

1. If the monetary authority picks coin sizes optimally (conditional on $\eta$ ), then ex ante welfare is higher if there are two coin types than if there is just one. A second, large coin potentially reduces the carrying cost of any given amount of coin wealth that an agent wants to hold.

2. The optimal coin sizes in two coin economies span the size of the optimal coin in a single coin economy. For example, if there are two coins and the larger weighs three times as much as the original coin, the ex ante welfare maximizing single coin is of size $b_{1}=0.009$ and the two coins have sizes $b_{1}=0.007$ and $b_{2}=0.021$.

3. Introducing a second coin does not always raise ex ante welfare. For example, consider an economy with a single coin of size $b_{1}=0.006$. Ex ante welfare is higher than in an economy with two coins of sizes $b_{1}=0.002$ and $b_{2}=0.006$. It is also the case if we 


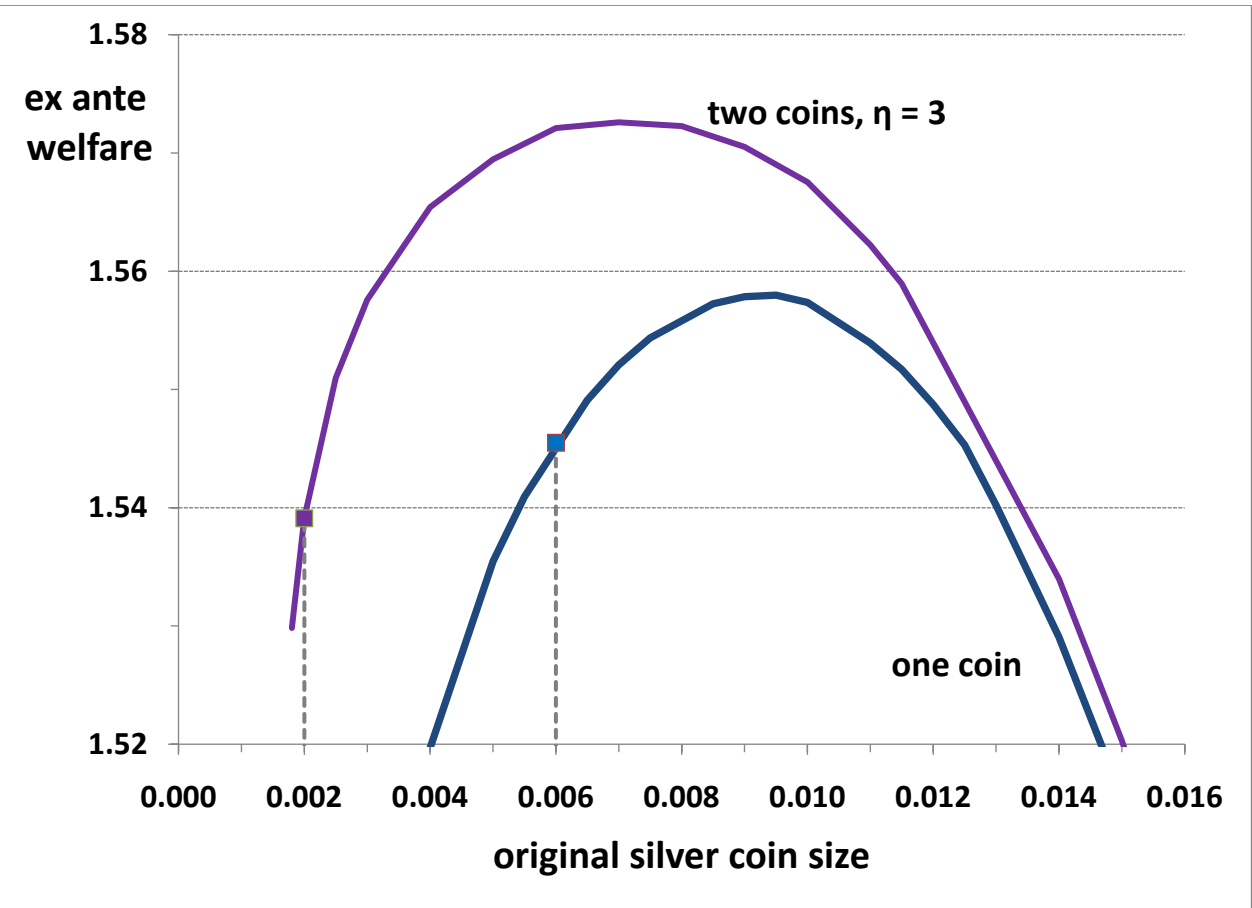

Figure 4: Optimal coin sizes if there are two coins 
compare an economy with a single coin of optimal size $\left(b_{1}=0.009\right)$ with an economy with that coin and a smaller one, $b_{1}=0.003$. This is true even though the amount of each coin minted is endogenous in both cases. That is, even though agents would be better off as a group, in an ex ante sense, if they minted no small coins when given the chance, it is in their individual interests to mint them.

\section{Historical application of the model}

We now use the model to analyze the choices of coin size in Venice and in England through the Middle Ages. These two regions represent very different aspects of the medieval European economy. Venice, one of several city-states in Northern Italy, was a prosperous city benefitting from ties with the dynamic Mediterranean economy. The city was ruled by a mercantile elite. In contrast to the fragmented Italian city-states, England was a centralized polity by the High Middle Ages, ruled by a monarch, and where the landed nobility held more power than the mercantile class.

Two of the most important changes in the economic environment in the Middle Ages were the growth of urbanization and increases in silver mining. We briefly describe these changes and how their impact differed in extent and chronology between Venice and England. We then show how such changes would affect the optimal coin size in our model. We find that the observed changes in the coinage in Venice and England correspond to the changes that would raise welfare in our model. On this basis, we argue that as the economic environment changed, the optimal coin size changed and that this influenced the monetary authorities' choice of coin sizes. In other words, our model supports the view that decisions about coin sizes during the medieval period reflected, at least in part, a desire to improve the economic welfare of the general population and explicates the mechanisms whereby it did so.

\section{A. Urbanization and the reduction in coin sizes}

Economic historians have described the "renaissance of markets" between the 10th and 13th centuries in Europe as a process that began in Northern Italy and spread gradually and intermittently to the Low Countries, France, and England (e.g., Epstein (2009), ch. 4).

Outside the Muslim territories in Europe, Northern Italy was the most prosperous European region in AD 1000 with a highly urbanized population and an emerging commercial sector. By the 11th century, perhaps as much as $14 \%$ of the population lived in cities of more than 10,000 (compared with 10\% in Belgium and less than 5\% in the British Isles and France (Van Zanden (2009), p. 40). Venice was one of the four richest cities in the region (the others: Genoa, Milan, and Florence) with a population estimated at 45,000 in AD 1000. Over the next three centuries, the population rose to 110,000 as the city grew with expanding Mediterranean trade and Venice became the major entrepot for the Levantine trade.

The acceleration of commercial activity and urbanization in England came much later than that in Venice. At the beginning of the 13th century, the population of London is estimated to have been 40,000 (Chandler (1987)). Starting then and continuing through the 13th century, economic activity in England expanded with the population increasing and the growing wool trade and urbanization accompanying an expansion of commercial activity. In his study of the growth in the number of market towns between 1200 and 1349, Britnell (1981) shows that over the period 1200 to 1350 the most rapid expansion (in number and activity) occurred in the 25 years between 1250 and 1274 . 
If we interpret changes in urbanization as increases in the frequency of trading opportunities available to agents, we can evaluate their effect on optimal size in our model. The frequency of trading opportunities affects the optimal coin size as shown in Figure 5. As the frequency of trading opportunities $(\theta)$ increases, optimal coin size initially increases but then steadily decreases.

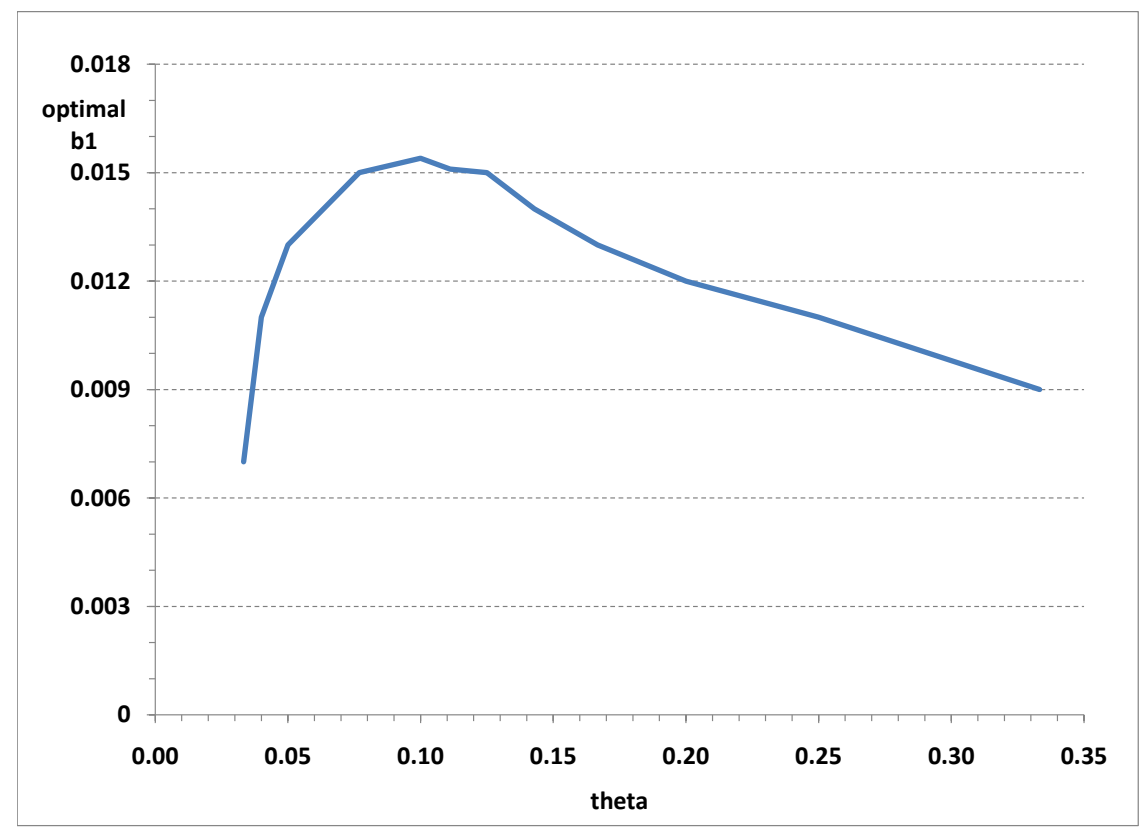

Figure 5: Optimal coin size for different amounts of trading

When trade is very infrequent $(\operatorname{small} \theta)$, agents do not want to hold much silver in the form of coins and would prefer to keep their wealth in utility-yielding jewelry. Small-sized coins permit them to do this while still affording them the opportunity to trade when they happen to be the buyer in a single coincidence match. As trade becomes more frequent, agents are willing to hold more wealth in the form of coins, and the cost of using small coins $(\gamma)$ starts to matter more, leading them to want larger coins. After some point, here $\theta=0.1$, however, the increasing amount of trade means that the flexibility in the offers more than offsets the handling cost of more coins, and so agents would prefer a smaller coin (on average).

The coinage changes mandated by the Venetian and English monetary authorities are consistent with welfare-enhancing responses to urbanization predicted by our model. Further, also consistent with our model, the differences in the timing and extent of urbanization caused these responses to occur at different times in the two locations.

In the case of Venice, the growth of commercial activity occurred between AD 1000 and AD 1200. It was accompanied by the gradual but cumulatively large reduction in the silver content of the denarius from 1.6 grams to approximately 0.1 grams.

The change in English coinage was later and of a different nature. Before the 13th century there was very little reduction in the silver content of the penny, and by 1200 
the English penny contained roughly 14 times as much silver as the Venetian denarius. In 1279, right after the period of expansion that Britnell (1981) highlights, the English did begin to mint coins with less silver, but rather than debasing the single coin, they began minting additional coins containing 0.67 grams (halfpence) and 0.33 grams (farthings) of fine silver. Notice that even after 1279, the smallest English coin (the farthing) had considerably more silver than the denarius. This may reflect the fact that Northern Italy was still more urbanized than England. It is also consistent with our finding (in Section 3.1) that a monetary authority that favors the wealthy (e.g., the landed elite in England) would choose a larger coin size than a more egalitarian monetary authority.

\section{B. Silver inflows and the introduction of large silver coins}

Available evidence suggests that the quantity of silver in Europe was relatively static until the mid-12th century. This changed in approximately 1160 with the discovery and exploitation of silver mines at Freiberg (in what is now Germany). ${ }^{5}$ Indeed, Spufford (1988) titled the relevant chapter of his seminal monetary history of medieval Europe "New silver, c.1160-1320." The new silver found its way first to the Italian cities, the most commercialized and trade-oriented part of the continent, and particularly to Venice, the nearest city to the mines (Lane and Mueller (1985), p. 138).

The new silver found its way to England more slowly. Direct balance of payments evidence is not available, but estimates of the money stock provide indirect evidence of this timing. Figure 6 uses the estimates of Allen (2001) for the amount of coin in circulation and of Clark (2007) for the English population. The figure shows a tripling of coin stocks per capita between 1279 and 1310 .

Figure 7 shows how the size of the silver coin affects the ex ante welfare for various levels of the stock of metal per capita $(m)$. When there is more silver, agents are wealthier on average, and they would choose to hold more silver both in the form of coins and in the form of jewelry. A larger size coin allows them to do this with lower handling costs, so that optimal coin size increases with $m$ when there is only a single coin in the economy. ${ }^{6}$

However, our model suggests that there is a better response to increasing the size or the single coin. This is to add a second, larger coin. Consider an economy in which there is a single coin of size $b_{1}=0.009$. If the monetary authority adds a second coin that is three times as large as the existing coin when the per capita stock of silver doubles, it will raise welfare relative to the option of minting only a single coin even if the size of that coin is chosen optimally. This is shown in Figure 8.

Once again, the coinage changes mandated by the Venetian and English monetary authorities are consistent with welfare-enhancing responses to the increasing stocks of silver in the High Middle Ages. Venice started minting a new large "great" silver coin — the grosso - in the last decade of the 12th century, shortly after the discovery of silver in Freiburg. The grosso contained approximately 24 times as much silver as the denarius. England, which

\footnotetext{
${ }^{5}$ As numismatists and historians note, while rough measures of the quantity of silver mined can be estimated, the initial stock is not known. The conclusion as to the significance of the increase in part rests on the anecdotal discussion of contemporaries and on the change in volume of activity at mints.

${ }^{6}$ Figure 7 makes it appear that optimal coin size increases proportionately with $m$. This is not true in general but is the result of our particular parameter choices.
} 


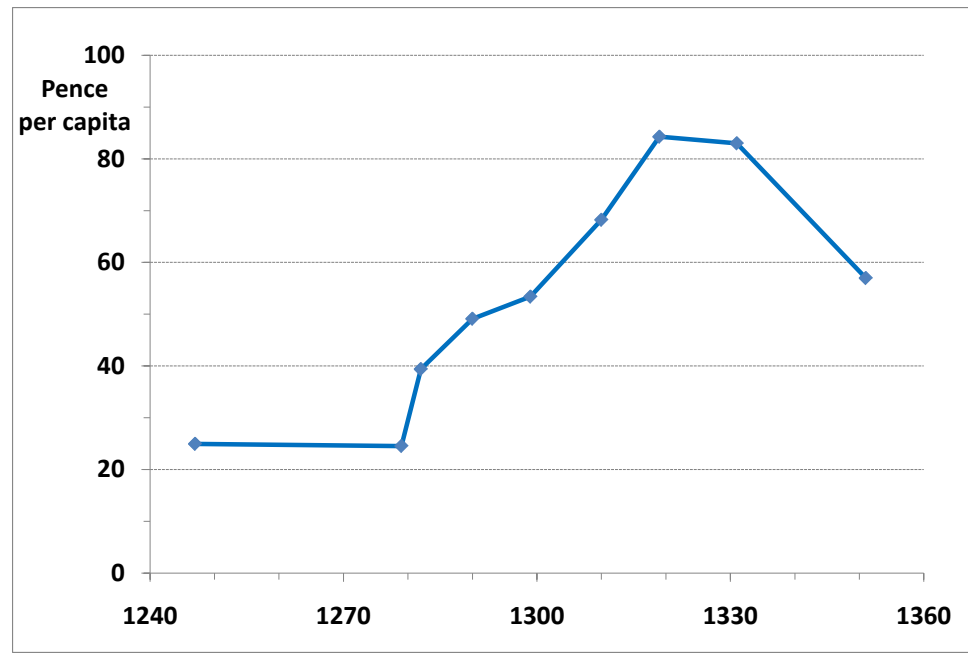

Figure 6: Value of silver coin stock per capita, England, 1247-1351

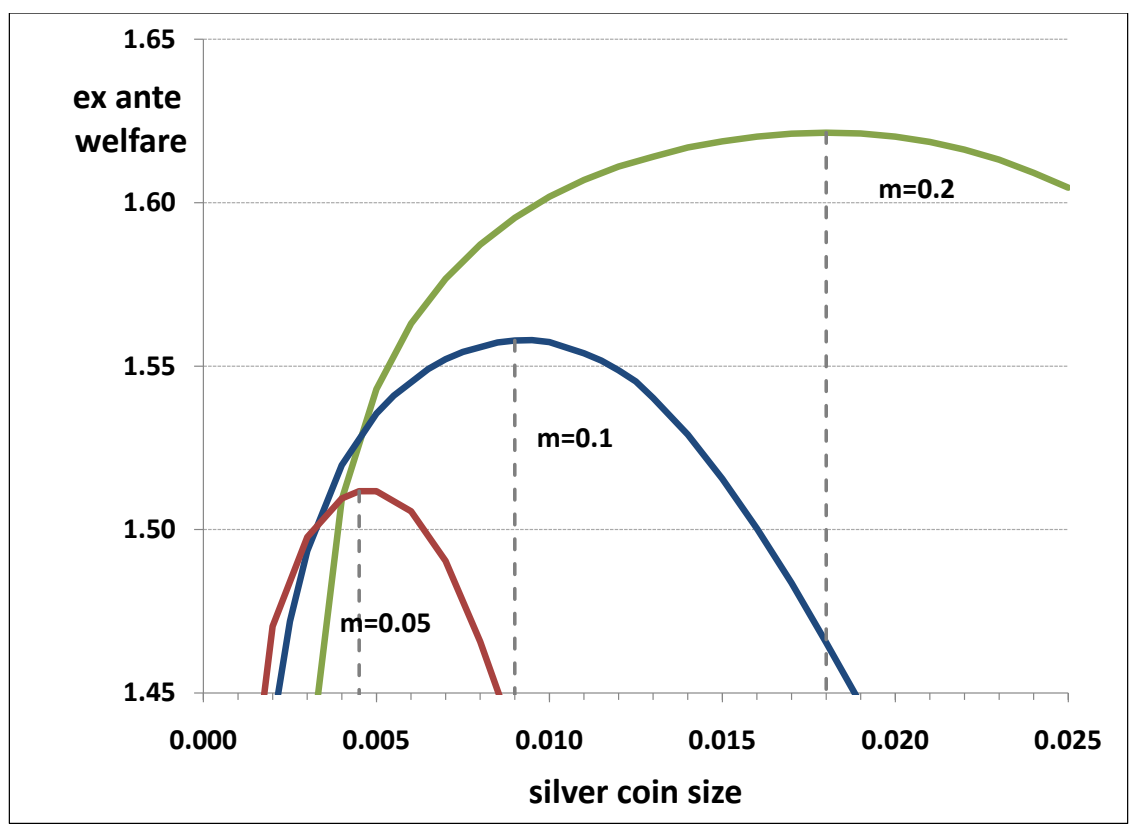

Figure 7: Ex ante welfare for different $m$ 


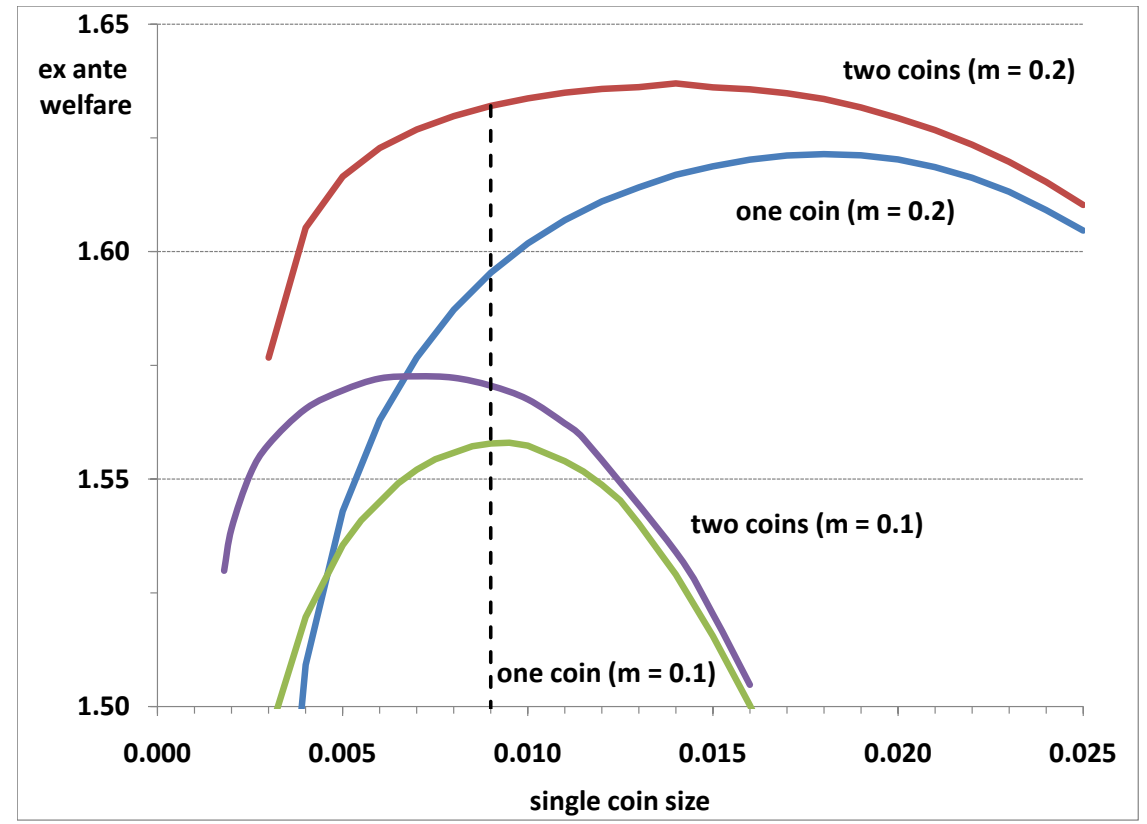

Figure 8: Welfare gains from a second coin

received the inflow of silver later, introduced the groat in 1351 . The groat contained about 4 times as much silver as a penny (and still had more than twice the silver content of the grosso). ${ }^{7}$ Interestingly, in England the mint indenture of 1279 had made provision for the minting of groats, but few (probably none) were minted. There were no complaints of a groat scarcity.

\section{Relation to other explanations}

We have argued that the major changes to the types of coin in circulation in Europe in the Middle Ages can be seen as efforts to adjust the coinage to the external economic environment. Here we compare our explanations for the differential experience of debasement and for the timing of the introduction of large silver coins in Italy and England with those currently in the literature.

\section{A. Explanations for debasements}

The most commonly accepted view of debasements is that they were driven by fiscal motives. For example, Epstein (2009) (p. 233) described debasement of the silver currency as "a source of profits, as a literal means to make money," and Hunt and Murray (1999) (p. 127) described medieval governments which "sought to raise funds by debasing the coinage, the medieval equivalent of printing money." In addition, Spufford (1988) titled the chapter of his monetary history that describes debasements in the 13th to 15th centuries as "The

\footnotetext{
${ }^{7}$ Similarly, France introduced the gros in 1266. Large silver coins (called variously groschen, gros, etc.) were introduced in the Low Countries and Rhineland in the mid-14th century. See Grierson (1991).
} 
Scourge of Debasement." He argued that "debasement was, of course, generally a byproduct of war," with the exception being "occasional minor downward adjustments in the weight of new coins dictated by the state of wear of the coinage already in circulation" (p. 289).

Historians of Venice have been much more nuanced, however, and have argued that the gradual debasement of the denarius between AD 800 and AD 1200 was not fiscally motivated, but was a reasonable response to economic expansion that exceeded the growth of monetary metal. One example is Cipolla (1963). He argued that the dramatic growth of the Italian population between the mid-9th and mid-13th centuries and simultaneous increase in the division of labor significantly increased the demand for money. Since the supply of precious metals did not expand proportionately to the increase in the demand for money, there would have been a "dangerous downward movement of prices" had not measures been taken "to reduce the fineness of the coinage and increase the number of pieces in circulation." 8

Our model enables us to evaluate Cipolla's analysis. To do so, we compare the optimal coin size (conditional on a fixed quantity of monetary metal) in two economies with different matching probabilities (different $\theta$ ). This is done in Table 3. The first row of the table shows average price in terms of coins $(\bar{p})$, average price in terms of ounces of silver $\left(b_{1} \bar{p}\right)$, average coin holdings, and ex ante welfare for an economy with $\theta=1 / 9$ and a coin size of $b_{1}=0.015$, which is the optimal size coin for this economy. ${ }^{9}$ The next row shows the same items when $\theta$ has increased to $1 / 3$, but the size of the coin is unchanged. The final row shows the same items for $\theta=1 / 3$, but with a smaller coin size of $b_{1}=0.009$, which is the optimal size coin for that economy.

A comparison of the second row with the third shows shows that Cipolla is correct about two points. First, the number of silver coins in circulation is larger with the smaller coin. Second, the average price, in terms of both silver and the number of coins, is higher with the smaller coin.

However, even though our model's predictions accord with what Cipolla asserts would happen in the absence of debasement, the mechanisms are entirely different. He seems to take a quantity theory view with the money stock being the quantity of coins in existence. The increase in this money stock is required to keep the price level in terms of coins from falling when output increases. He seems not to recognize that under his outcome there would be still deflation in the sense that the price of output in terms of silver would have decreased. In contrast, in our model, the price of output in terms of silver depends on how valuable silver is as jewelry relative to how valuable it is expected to be if turned into coins. The price of output in terms of coins depends on how much metal is in the coin.

Lane and Mueller (1985) (p. 25), in their seminal history of money in Venice, argue,

\footnotetext{
${ }^{8}$ Also note that while Cipolla (1963) argued that the supply of precious metal was inelastic, he discussed the availability of metal through trade rather than the other margin that was closer to home, the undoubted availability of silver in the form of plate.

${ }^{9} \bar{p}$ is defined as

$$
\bar{p}=\sum_{y, \tilde{y}} \pi(y) \pi(\tilde{y}) \frac{p_{1}(y, \tilde{y})}{q(y, \tilde{y})} .
$$

The average number of coins traded appears exceedingly large at first glance. However, it must be remembered that the calculation is coins per unit of output. For our parameterization, the optimal output in a trade is only $q^{*}=0.1575$ and the vast amount of trades involved levels of output well below this level.
} 
Table 3: The effect of changes in $\theta$ and coin sizes

\begin{tabular}{cccccc}
$\theta$ & $\begin{array}{c}\text { Coin size } \\
\left(b_{1}\right)\end{array}$ & $\begin{array}{c}\text { Average price } \\
\text { in coins }(\bar{p})\end{array}$ & $\begin{array}{c}\text { Average price } \\
\text { in ounces of silver }\left(b_{1} \bar{p}\right)\end{array}$ & $\begin{array}{c}\text { Average coin } \\
\text { holdings }\end{array}$ & Welfare \\
\hline \hline $1 / 9$ & .015 & 47.4 & 0.711 & 1.74 & 0.531 \\
$1 / 3$ & .015 & 12.9 & 0.193 & 1.28 & 1.52 \\
$1 / 3$ & .009 & 27.3 & 0.246 & 2.24 & 1.56
\end{tabular}

"The above-mentioned debasement of imperial pennies by Italian mints from the ninth century to the twelfth has usually been attributed to the greed and completion of local lords, but it probably was in the public interest, because it met a growing need for coin that arose from the increased use of markets and the general expansion of trade." The predictions of our model support their explanation.

\section{B. Explanations for the introduction of larger coins}

We have argued that the large silver coins were introduced because of an increase in the stock of monetary metal in western Europe, an increase that was experienced first in Northern Italy and later in England. The conventional explanation for the introduction of large coins has focused more on urbanization and the expansion of the urban workforce as the relevant exogenous change.

In his article explaining the introduction of the grosso, Grierson (1979) attributed the new coin to the necessity of paying wages for the construction of ships for the Fourth Crusade in 1200. For the English case, Spufford (1988) specifically rejects the notion that there was too little monetary metal in 1279 to justify a groat coinage and argues that the groat was popular after 1351 because of an increase in urbanization, more wage-earning workers, and higher wage rates.

Although Grierson's argument quickly became the conventional wisdom (see Spufford (1988)), work by Lane and Mueller (1985) and more recently Stahl (2000) has shown that the grosso was introduced in the early 1190s, before the outfitting of the Crusade. That is, creation of the grosso cannot have been motivated by the need to pay those workers. ${ }^{10}$

Spufford (1988) argued that the most important difference in England between 1279, when the groat was mooted but not minted, and 1351, when it became the most minted silver coin, was the amount, frequency, and level of urban wage payments. Wages are perhaps the easiest variable to quantify, and he noted that building-labourer wages were about $9 \mathrm{~d}$ per week in 1280 and "in the 1350s their [workers'] wages were in the process of doubling." He also argued that there was "probably less coined money in England in 1351 [than in 1279]."

New research has challenged Spufford's empirical assertions. Robert Allen showed that building craftsmen in London earned $4 \mathrm{~d}$ per day in 1279 and $5.3 \mathrm{~d}$ in $1351 .{ }^{11}$ It was

\footnotetext{
${ }^{10}$ This is not to deny that the popularity of the grosso would have been assisted by the massive inflow of silver (enough to mint 4 million grossi) provided for constructing the Crusaders fleet.

${ }^{11}$ The data are from a data file maintained by Robert Allen: "Prices and wages in London and Southern England, 1259-1914" available at www.nuff.ox.ac.uk/users/allen/studer/london.xls.
} 
not until 1413 that wages "doubled." Additionally, Allen (2007)'s work showed exactly the opposite of Spufford's assertion about the amount of coined money in England (see Figure 6). Indeed, even in his own later work (Spufford (2002) p. 12), he argued for a much greater stock of silver ("a twenty-four fold increase") in 1319 than in the mid-13th century, although he was not precise about the timing of that increase.

In summary, previous studies have emphasized the importance of rising wages and numbers of wage workers for the introduction of large silver coins; however, the empirical evidence is not supportive of this linkage. The evidence does show that the introduction of large silver coins was preceded by increases in the stock of silver in the economy. Our model shows that in the face of increased silver stocks, increasing the coin size increases welfare, and we conclude that the monetary authorities were responding to the larger metal stocks when they commenced issuing the groats/grossi.

\section{Conclusion}

In this paper, we construct a random matching model of a monetary economy in which the medium of exchange available to agents is commodity money in the form of potentially different types of silver coins that are distinguishable by the quantity of metal they contain. The quantity of silver in the economy is assumed to be fixed, but agents are permitted to adjust the quantities of coins they hold by minting and melting. Coins are assumed to yield negative direct utility because they are costly to hold, but they are valued because they are the only objects that agents can trade to obtain consumption. However, uncoined silver can be held in the form of jewelry that does yield direct utility to the holder.

Although we are unable to obtain analytical results for the model, a numerical analysis yields these results:

1. In a single coin economy, the optimal size of the coin at first increases and then decreases with the probability that an agent is able to trade.

2. In a single coin economy, the optimal size coin increases with the stock of silver.

3. If coin sizes are chosen optimally, then welfare in an economy with two coins is always higher than in an economy with a single coin.

4. However, adding a second coin to an economy with an existing coin may increase or decrease welfare depending on the size of the existing coin.

We then use these predictions of our model to analyze the coinage decisions of the monetary authorities in Venice and England. Our model provides theoretical support for the view that decisions about coin sizes and types during the medieval period reflected, at least in part, a desire to improve the economic welfare of the general population, not just the desire for seigniorage revenue on the part of the sovereign. 


\section{References}

Allen, M. (2001): "The Volume of the English Currency, 1158-1470," Economic History Review, 54(4), 595-611.

(2007): "The Proportions of the Denominations in English Mint Outputs, 13511485," British Numismatic Journal, 77, 190-209.

Britnell, R. H. (1981): "The Proliferation of Markets in England, 1200-1349," Economic History Review, 34(2), 209-221, New Series.

(2004): "Uses of Money in Medieval England," in Medieval Money Matters, ed. by D. Wood, pp. 16-30. Oxbow Books, Oxford, England.

Challis, C. (1992): A New History of the Royal Mint. Cambridge University Press, Cambridge.

Chandler, T. (1987): Four Thousand Years of Urban Growth: An Historical Census. Edward Mellon Press, Lewiston, NY.

Cipolla, C. (1963): "Currency Depreciation in Medieval Europe," Economic History Review, 15(3), 413-422, New Series.

Clark, G. (2007): "The Long March of History: Farm Wages, Population and Economic Growth, England, 1209-1869," Economic History Review, 60(1), 97-135, New Series.

DE WAilly, N. (1857): Mémoire sur les variations de la livre tournois depuis le règne de Saint Louis jusqu'à l'établissement de la monnaie décimale, vol. 1. Johns Hopkins University Press, Baltimore, Coins and Moneys of Account.

Epstein, S. (2009): The Economic and Social History of Later Medieval Europe, 1000-1500. Cambridge University Press, New York.

Favier, J. (1998): Gold and Spices: The Rise of Commerce in the Middle Ages. Holmes and Meier, New York.

Grierson, P. (1979): "The Origins of the Grosso and of Gold Coinage in Italy," in Later Medieval Numismatics, ed. by P. Grierson, pp. 72-86. Variorum Reprints, London, England.

(1991): The Coins of Medieval Europe. Seaby, London.

Hunt, E. S., And J. M. Murray (1999): A History of Business in Medieval Europe, 1200-1550. Cambridge University Press, New York.

Lane, F., And R. Mueller (1985): Money and Banking in Medieval and Renaissance Venice, vol. 1. Johns Hopkins University Press, Baltimore, Coins and Moneys of Account.

Lee, M., N. Wallace, and T. Zhu (2005): "Modeling Denomination Structures," Econometrica, 73(3), 949-960. 
Mayhew, N. J. (2004): "Coinage and Money in England, 1086-c.1500," in Medieval Money Matters, ed. by D. Wood, pp. 72-86. Oxbow Books, Oxford, England.

Redish, A., And W. E. Weber (2011): "Coin Sizes and Payments in Commodity Money Systems," Macroeconomic Dynamics, 15(Supplement 1), 62-82.

Spufford, P. (1988): Money and Its Use in Medieval Europe. Cambridge University Press, Cambridge.

(2002): Power and Profit: The Merchant in Medieval Europe. Thames and Hudson, London.

Stahl, A. (2000): Zecca: The Mint of Venice in the Middle Ages. Johns Hopkins University Press, Baltimore.

Van Zanden, J. L. (2009): The Long Road to the Industrial Revolution: The European Economy in a Global Perspective, 1000-1800. Brill, Boston.

Velde, F. R., And W. E. Weber (2000): "A Model of Bimetallism," Journal of Political Economy, 108(6), 1210-1234. 